\title{
RECONSTRUCTION OF THE CRIMINAL SANCTION POLICY AND ACTION (DOUBLE \\ TRACK SYSTEM) IN LAW ENFORCEMENT FOR NARCOTIC CRIME PREVENTION REFFERED TO RELIGIOUS JUSTICE
}

\author{
Carto Nuryanto \\ The Directorate of Narcotics at the Central Java Regional Police \\ cartonuryanto@gmail.com
}

\begin{abstract}
Narcotics abuse is a dangerous problem that can impede the progress of the Indonesian nation in implementing development in every sector of life. At that time, this country is only a transit area for illicit goods to be shipped to Australia or to other Asia Pacific countries. But two decades later, Indonesia has become a lucrative market for the drug dealers. The problems faced today are related to the drug is that North Sumatra ranked third after Jakarta and East Kalimantan in the rate of drug users. Setting up a rehabilitation center for criminals, especially drug is a solution. They need the healing process of the illicit drug dependence. Jail is not the best solution for this problem, hold but also perform medical therapy before going to work and we call it "double track system". It's no secret that many drug users in Penitentiary but still drug dependence. This is because they just physically restrained but the disease has not been cured. They need treatment that has not been achieved. They need treatment that has not been achieved because they just physically restrained but the disease has not been cured. They need treatment that has not been achieved.
\end{abstract}

Keywords: Narcotics Abuse, Reconstruction Law Enforcement, Religious Justice.

\section{A. INTRODUCTION}

Narcotics on one side is a drug and useful materials in the field of medicine or health services and the development of science $^{1}$, but on the other hand can Narcotics lead to dependence if misused, so it can lead to physical, mental, social, security and public order which eventually disrupt national security nor international.

1 Badan Narkotika Nasional, 2004, Kampanye Anti Narcotics, Sinar Grafika, Jakarta, p. 13 
be producers of goods that can make sense of hovering $\mathrm{it}^{2}$.

The problems faced today are related to the drug is that North Sumatra ranked third after Jakarta and East Kalimantan in the rate of drug users. UN since 1987 set June 26 as day Opium world by International Day Against Drugs. Narcotics National Agency (BNN) mentioned drugs every year kills 15,000 people. Ironically children abusers actually increased the number of drug users. At present, there are about 3.2 million narcotics users. Total obvious benefit producers. Bas on YCAB (Love Child Foundation), a foundation that are concerned about the dangers of drugs, the number of drug users rose from $8 \%$ in 2001 to $11 \%$ in 2006. Law enforcement against narcotics criminal acts have been carried out by law enforcement officers and have a lot to get the judge's decision in court this law is expected. Law enforcement as deterrent factor against widespread circulation of the drug trade, but in reality even more conducted intensive law enforcement, also increase the trade circulation. has reached the level of Very worrying. According to the Minister of Law and Human Rights, Amir Syamsuddin, in 2011 recorded discomfiture of 98 cases of drug smuggling in rehabilitation institute. While the year 2012 reveal 12 new drug cases $^{3}$. The problems occur that Rehabilitation institution in Indonesia is one of the market for drug dealers. Many drug users detained at the Correctional Institution Their average This has caused money. Often they have not been in a state of recovery but still a dependency on drugs. The problem happens when we assume that drug users that have characters like common criminals so they can be mixed with other inmates. Yet those who use drugs are in a state of drug dependence physically and psychologically ill ${ }^{4}$.

Overview of Narcotic Abuse

Opioid drugs, also called opiates or narcotics, have been used since the beginning of recorded history. Opium is derived from a white liquid produced by the poppy plant, first cultivated in the

3 Leden Marpaung, 2005, Tindak Pidana Terhadap Nyawa Dan Tubuh, Sinar Grafika, Jakarta, p.64

4 SR.Sianturi, 2002, Asas-Asas Hukum Pidana DiIndonesia, Rineka Cipta, Jakarta,p. 57 
Middle East and Asia. It was used therapeutically in ancient cultures to induce calm and to relieve pain, and recreationally to induce euphoric dream states. Today, physicians prescribe narcotics for pain relief. Whether plant derived (natural) or synthetic, narcotics are sometimes still referred to as opioids.

Narcotics produce intense pleasure and general calmness:

1) Drowsiness,

2) tranquilization, or sleep Feeling of well-being Pain relief (analgesia)

3) Temporary euphoria;

4) a "high"

Narcotics like morphine, heroin, codeine, opium, hydrocodone, oxycodone,

meperidine, and methadone bind to certain painkilling sites in the brain. With consistent use, they build up in the brain and block the production of endorphins, the brain's natural painkilling chemicals. Opium, morphine, and heroin (a derivative of morphine) were commercially available for purchase in the United States throughout the 19th century.
For complaints of diarrhea, menstruation, and headache, physicians commonly prescribed opioids in the form "tonics," elixirs," and "cordials" much in the way aspirin is used today. Their use, and even abuse, was less likely to be seen as problematic. Opium dens provided a place for people to smoke the drug. However, as policy makers began to address the social consequences surrounding narcotic addiction, drug use became stigmatized as a lower-class recreation. Shortly thereafter, the general public became intolerant of narcotic, now illicit, drug use. Abuse was defined as a problem and using heroin and smoking opium were eventually made illegal.

Narcotic abuse is defined by impaired function and interference in the daily life of the user. Users often develop serious physical, social, and mental health problems that compromise well-being and affect family and friends. Narcotic abuse costs the nation $\$ 10$ billion a year in treatment, care, and lost productivity; this does not include the cost of treating use-related diseases, like AIDS. Incidence and Prevalence of Narcotic Abuse 
The U.S. Food and Drug Administration (FDA) reports that more than 16,000 people die from an opioidrelated overdose each year in the United States. According to the Centers for Disease Control and Prevention (CDC) in April 2014, the number of drug overdose deaths in the United States have increased regularly for more than 10 years-surpassing car crashes as the leading cause for injury death in 2013.

Misuse and abuse of prescription pain relievers, as well as illicit opioids like heroin, have become a major public health concern. Men in the United States use illicit drugs slightly more than women. Narcotic abuse among non-Caucasian people is reportedly highest, especially in urban areas.

Addiction: How Narcotics Work

The biochemical effects of narcotic drugs are what make them addictive. Narcotics bind to painkilling sites throughout the brain, known as opioid-U receptors or the "reward pathway." This leads to slower uptake of neurotransmitters, like dopamine, between neurons.

Immediate effects include cessation of pain, drowsiness, and a feeling of well-being associated with pain reduction. With chronic use, the brain may stop producing endorphins, natural painkilling chemicals, and the user develops tolerance. The user must replace the missing endorphins with narcotics in order to feel good and to avoid the painful effects of narcotic withdrawal. The user becomes dependent on increasing amounts of the drug to feel good. Abuse usually leads to dependence.

Addiction is a chronic illness of the brain. Although one initially chooses to use narcotics, addiction is more than a behavioral problem; it is physiological and psychological. Compulsive use and relapse after recovery are a few of the behavioral problems that result from dependence. Use and relapse may be enforced by environmental cues, like peer influence and specific cultural stimuli. Breaking the habit of drug addiction is difficult and requires detoxification, changes in lifestyle, and therapy.

Risk Factors for Narcotic Abuse

Psychological and environmental risk factors for narcotic use include the following: 
1) Antisocial and experimental attitudes (i.e., rebellious nature) during adolescence

2) Environmental factors Family problems

3) Gang membership

4) Inner-city culture

5) Poverty

6) Wealth or disposable income

7) Family history of substance abuse and drug addiction

8) Low self-esteem

They need medical rehabilitation to recover condition. When inserted Penitentiary without any medical treatment then this does not solve their problems because they are in a state of drug dependence. Attempts to perform on the narcotics user in rehabilitation institution only will temporary halt. Root of the problem is precisely the existence of sizeable demand for drugs and their offers for the resulting transaction.

They are in prison in the position of drug dependency and all ways will be done to get the drug. During this time they do not get treatment at the Correctional Institution for reducing drug habit so that the condition still remains sick. Coupled with prison conditions in Indonesia are mostly already excess capacity. This condition can worsen the situation, some of the prisoners who was not involved in the network drugs can only be a dealer. For example Inmates motocycle stealing for interacting with the drug could be the next dealer even recidivist, it may also bring new problems again.

Setting up a rehabilitation center for criminals, especially drug is the solution. They need the healing process of the illicit drug dependence. Jail not the best solution for this problem, hold but also perform medical therapy before going to work. It's no secret many users drug that in rehabilitation institution but still drug dependence. This is because they just physically restrained but the disease has not been cured. They need treatment has not been achieved ${ }^{5}$.

Those who are in Penitentiary in the condition of drug dependence should indeed get the right medical treatment and rehabilitated so that instead of being in an environment of fellow Prisoners who are still addicted to drugs like today. This condition can actually aggravating circumstances of their dependence on drugs. 
Development based rehabilitation centers penitentiary are required to enable the handling of drug offenders to appropriate treatment.

\section{B. DISCUSSION}

There are currently three types of emergencies (Form colonization) that Indonesia is facing a very dangerous and even threaten the future of this nation and generation, ie Abuse of Narcotic/Drugs, Pornography and also acts happy import everything from abroad. Three state this is a phenomenon that now we think is prevalent but the impact for generations and the future of the nation Indonesia is huge because especially the youth as a generation of people who are often the victim who was immersed enjoyed it so negligent in carrying out their duties and obligations as a youth and the next generation. One of the three states that also included in the category of offense is the abuse of narcotics.

Looking at the general provisions of Act. No. 35 of 2009 on Narcotics explained that Narcotics are substances derived from plant or not plant, synthetic or semisynthetic, that can be caused a decrease awareness, loss of taste, reduce to eliminate pain, and can lead to dependence, which are divided into groups attached in the Act. No. 35 of 2009.

Narcotics abuse today is increasingly rising anyway. We can see from the news-good news in print and electronic media almost every day preaching about the arrest of the abusers of narcotics by the state through the National Narcotics Agency (BNN) and the Indonesia National Police (INP). Widespread abusers and victim of this narcotic crime has penetrated all of society without exception ranging from children, teenagers, young people, older people, both educated and uneducated and from various types of professions.

In Act. No. 35 Of 2009 on Narcotics also have mentioned about some of the terms that have the same essence with the Narcotics itself, among other things Narcotic Addict, Victim abusers, ex-addicts Narcotics and Patient. Base from a variety of diverse related with abusers of narcotics so that the impact and implications of different so there are inconsistencies in terms of treating people who use drugs as 
victims of abusers of narcotics for themselves.

In principle Abuse To narcotics are guaranteed medical rehabilitation and social rehabilitation as set out in Article 4 paragraph (d), and Article 54 which states that "Addicts Narcotics and Narcotics Abuse required to undergo medical rehabilitation and social rehabilitation" but in the penal provisions have also been arranged criminal sanctions for people who use drugs as stipulated in Article 127, which reads:

a Every Abuse To:

1. Narcotics Group I for myself is liable to imprisonment for a period of 4 (four) years;

2. Narcotics Group II for yourself is liable to imprisonment for a period of 2 (two) years; and

3. Narcotics Group III for themselves shall be punished with imprisonment for a period of 1 (one) year.

However, because the Indonesian Criminal Justice System adheres to the principle of legality in general practice, all cases of narcotics including User narcotic traffickers themselves are not usually also always be prosecuted in accordance with legal norms as stipulated in Law of Narcotics is a penalty of imprisonment. So Abuse To narcotics for themselves who are not dealers where originally as victims should be rehabilitated must undergo imprisonment under Article 127. Not only limited to these users are not drug dealers when presented in front of the hearing will be charged with other overlapping. Logically users who obtain narcotics illegally, then of course there are also simultaneously several actions performed by users, formulated in Article 111 and Article 112 or even Article 114 which has an element of purchasing, controlling, storing, or have eventually used alone.

Act on Narcotics themselves do not provide differentiation / clear line between criminal offense under Article 127 Narcotics Act with criminal offense others contained in the Narcotics Law, where drug users who receive narcotics unlawfully must meet the elements of "master", "have" , "store", or "buy" the drug where it is also regulated as a separate criminal offense under the narcotics Act. Between the criminal offense of drug users with criminal 
offense of control, ownership, storage or purchase of narcotics have been unlawfully and illegally where the criminal threat becomes much more high and using special minimum sanction that is at least 4 years in prison and a fine of at least $\mathrm{Rp} 800$ million.

A large number of cases of abuse of narcotic drug abusers especially for myself as well as the criminal policy (Criminal Policy) are addressing this as repressive as stipulated in Article 127 junto Article 111 and Article 112 or even Article 114 of Act. No. 35 of 2009 that emphasizes the retributive justice of course this will bring the logical consequence of the number of occupants in the Penitentiary in addition for users who are not a dealer who became a double victimization.

The number of Criminal Nara (NAPI) of narcotics in law based on the positive law in Indonesia caused the number of NAPI in Correctional (prisons) to dominate in addition yet special prisons narcotics inadequate, causing prisons in Indonesia full or over capacity (over load). It is also in line with what was stated by Deputy
Chairman of Commission IX of the House of Representatives, Nova Riyanti Joseph states that $70 \%$ of the inhabitants of prisons currently inhabited by those who lodged the case of narcotics. ${ }^{4}$ Of the 32 regional offices in Indonesian prisons 23 prisons have excess capacity and that does not exceed the capacity only amounts to 9 (nine) namely Yogyakarta, Central Java, Maluku, North Maluku, Papua, West Papua, West Sulawesi, South Sulawesi, Southeast Sulawesi. ${ }^{5}$

The occupancy rate that exceeds the capacity and the weakness of supervision over narcotics NAPI caused a lot of problems. This is evident from the frequent clashes between NAPI and between NAPI with prisons guards itself. The impact of things that we can see where the NAPI would flee, destroying prisons and even burn the prisons as it did on the day of Thursday, July 11, 2013, where prisons Tanjung Gusta 1 Class A, North Sumatra Medan on fire which resulted in around 300 ( three hundred) NAPI escaped. ${ }^{6}$

On the other hand the user collects, dealers, Airports, Importers and also the perpetrators of criminal acts qualifications other narcotics in the 
prisons then there is the narcotics market in the prisons. This situation can be seen with the frequency of the drug contained within the prisons and even some prisoners who control drug trafficking from within the prisons themselves, so in practice in the field prisons is where the safest drug transaction.

In Law Number 35 Of 2009 on Narcotics As for qualifications, tort categorized as narcotic crime consists of five categories, namely:

1. The first category;

All deeds in the form of possessing, storing, controlling or providing narcotics and drug precursors.

2. The second category;

All actions such as produce, import, export or distribute narcotics and drug precursors.

3. The third category;

All deeds such as offering for sale, selling, purchasing, receiving, being an intermediary in the sale and purchase, exchange or deliver narcotics and narcotics presecutor.

4. The fourth category;
All actions such as carrying, transfer, transport or presecutor and narcotics.

5. The five categories;

All acts of abuse Narcotics Group I, II and III for themselves.

Narcotics Abuse terminology for yourself normative is not explicitly stated in the Act 35 of 2009, however, only explain some of the terms that have almost the same essence with the abuser for yours.

One of the problems due to the many terms against drug users is gap setting where Article 4 letter d Narcotics Law which states the purpose of the legislation Narcotics is "Assuring setting attempts medical and social rehabilitation for abusers and drug addicts", but in Article 54 of the Narcotics Act states "addicts narcotics and narcotic abusers Victims shall undergo medical rehabilitation and social rehabilitation" so that rights abusers to get rehabilitation as provided for in Article 54 be not recognized by the threat of criminal sanctions for drug users as stipulated in Article 127.

Abusers of narcotics for yourself is kind of a crime without a victim "crime without victim" where narcotics 
abuse for yourself without being accompanied by deeds qualifications not other crimes such as dealers, manufactures, Importing, Exporting and various qualifications other in Act No. 35 of 2009 , as well as the perpetrators but also as victims of the crimes they have committed themselves.

In terms of victimology then abusers of narcotics for yourself is included in the typology of victims of "self victimizing Victims" that victims of crimes they have committed themselves. therefore then, most appropriate to do to him is a sanction actions and not criminal in prison for abusing narcotics for yourself is essentially a victim of a crime that needs to get treatment and / or care, and because he is the party also suffered loss of a crime the crime of drug abuse.

Losses suffered by drug users not only feel the loss of material, but also the loss of social, psychological, physical, and health. Social losses experienced by drug users in the form of stigma or stigma imposed by society, such as the designation of drug users are the dregs of society and other bad designations. Psychological losses experienced by drug users obviously unstable mental condition due to dependence on narcotic substances, especially if the drug users, especially injecting drug users infected with the HIV virus which causes those users eventually suffer AIDS. This is the health and physical losses as a result of the impact of injecting drug use doubled, not only got a bad seal due to drug addiction but also the stigma of being infected with $\mathrm{HIV}^{6}$.

If the terms of the health of abusers of narcotics for themselves, especially those who have experienced dependency has researched health experts and categorized as brain diseases or damage to the brain cells that work in the human body, where the body is controlled by the brain that has been disrupted due to the use of narcotic substances in the body resulting in the agent wants to be consumed continuously. As a result, criminal prosecution will not arbitrarily create dependence, these substances will recover and will not be using the substance again, but this dependence

6 Description Expert Host Winarso the decision of the Constitutional Court of the Republic of Indonesia Number 48 / PUU-IX / 2011, p. 67 
can only be tackled with medical and social processes ${ }^{7}$.

When the drug into the body will all work in the brain, so it will affect the behavior and mindset of the person. Such changes through a process called "Neuroadaptation". The longer a person uses drugs will be changes in the nerve endings in the function to receive and provide narcotic effects to a person's body, so that users have to increase the dose to get the same effect as before.

Hence their adaptationused amount of narcotic substances are gradually higher and when lowered or stopped altogether will cause withdrawal symptoms, drug users who make a person feel uncomfortable both physically and psychologically; Narcotics work in the brain in an area that "pleasure center", because of the pleasant effects due to the positive effects of brain caused difficult to erase the memory that has been recorded. When someone users see or feel something uncomfortable then it will be remembered is the use of narcotics back to get a sense of the pleasure. These conditions will lead to drug

7 Expert testimony Asmin Frances the decision of the Constitutional Court of the Republic of Indonesia Number 48 / PUU-IX / 2011, p 65 dependence someone who has become a chronic and relapsing disease because of the difficulty of releasing cells have receptors that bind addictive substances/narcotics.

Qualifications abusers of narcotics for themselves different from the types of qualifications other categorized as narcotic crime as Distributors, Importers, Exporters, Carrier, Sellers, who produce and type of other acts, which qualify the act is a crime that is very dangerous and impact losses great both on victims and the interests of the nation and the future generations to come. As for the victims of drug abusers for themselves are generally young men who should be the nation's generation. So in addition to qualifications drug users to themselves then any qualification narcotic crime criminal sanctions should indeed get a firm and heavy as possible in order to save the future generations of the nation and Indonesia.

Imprisonment of meaning nature is to eliminate and or limit the freedom of movement, in the sense of putting offenders in a place (Penitentiary) where offenders are not free to enter and exit and therein mandatory for 
subject to obey and execute all disciplinary rules which ruled. Between Criminal and Criminal Confinement Prison apparently the same, but both types of crime is actually differ greatly. Prison or correctional in Indonesia present term "is new discoveries that began to develop extensively these past 300 years. It is part of the criminal system development from time to time. Today imprisonment seen as form

criminal that aims to improve the socalled reform of criminals and criminal system that runs towards more rational. In contrast to the old view that aims to get rid of the criminals from society ${ }^{8}$.

Cause this is due to economic development, progress towards a human and appearance view

that more secular, the emergence of new concepts of human nature and society. although now said system criminalization moving towards the rehabilitation of criminals, the criminal nature itself as the violators of law may not be removed. Criminal system continues disputed by scholars, until now there has never been any satisfactory. The view eventually occur at the beginning of the 19th century with the advent of two conflicting views about the philosophy of punishment.

Sahardjo mentioned Prison Director elaborated in conference throughout Indonesia on April 27, 1964 Lembang, Bandung. at the conference That started a determination to improve inmate guidance system and students. Because Conference of Directors of Corrections Prison in Bandung on April 27 - May 7, 1964 receive the correctional system, then on April 27 taken as the Day of Corrections. Since 1968 used the term office of the Directorate General bina citizens, prisoners became Tuna residents.

In 1976 the Office of the Directorate General of Residents turned into Office of the Directorate General of Corrections, so tuna residents turned back into term prisoners. For the present time constraints in order to develop for inmates, especially financially very limited, followed by good infrastructure physical form of buildings and equipment as well as education the implementer correctional, in addition to the attitude of society itself difficult to leave the

8 Bambang Waluyo, 2000,Pidana Dan

pemidanaan, Sinar Grafika, Jakarta, p. 115 
nature of vengeance rather than a criminal being reformed ${ }^{9}$.

Imprisonment of its meaning is to remove and or limit the freedom of movement, in the sense of putting offenders in a place (Penitentiary) where offenders are not free to enter and exit and inside obliged to submit to obey and execute all disciplinary rules which ruled. Between Criminal and Criminal Confinement Prison apparently the same, but the second this criminal types actually differ greatly. Jail or the terms present in Indonesia "Socialization" is new discoveries that began to develop extensively the last 300 years. It is part of the development of the criminal system from time to time ${ }^{10}$.

Today's imprisonment is seen as a form of punishment that aims to improve the so-called reform of criminals and criminal system that runs towards more rational. Different with the old view that aims to get rid of criminals from community. Causes This change is due to the economic development, development towards the

9 Ibid., p. 119

10 Barda Nawawi Arief, 2011, Kebijakan Hukum Pidana Perkembangan Penyusunan Konsep KUHP Baru, Kencana Prenada Group, Jakarta, p. 42 
Jeremy Bentham devised a prison with the cell house roofed with glass walls overlooking a center where the guards in place.

System criminalization continue disputed by scholars, until now there has never been any satisfactory. The view eventually occur at the beginning of the 19th century with the advent of two conflicting views about the philosophy of punishment. Talking about the basic idea "Double Track System "means talking about a basic idea about the sanctions system on which to base policy and the use of sanctions in criminal law. In this case the two systems the sanctions in the law regarding the path of law enforcements. ide basis of this system is "Equality Between Criminal Sanctions and Penalties Measures". This idea equality can be traced to developments in criminal law sanctions system of stream flow to Modern Classical and Neo Classical Flow. classical flow in principle, only embrace the "Single Track System" the system single sanction in the form of sanctions. Sudarto said that the classical stream of retributive criminal and repressive against crime. This flow appears in the century XVIII that sensible indeterminism of freedom of the human will which emphasizes the deeds offenders. Criminal and conviction of this classic flow strongly emphasizes the criminalization of the act is not the culprit ${ }^{11}$.

In the nineteenth century was born flow because crime modern looking to use a method of natural science and intends to directly approach or positively affect criminals so long as he still can repaired. Modern flow regard freedom of the human will is influenced by nature and the environment that can not be blamed and convicted. As a consequence of the idea of "Criminal Individualization" then sentencing in the criminal justice system modern in turn oriented doer and deed This type of sanctions are set not only includes criminal sanctions, but sanctions. A proofment about equality between criminal sanctions and sanctions action is human nature or the basic idea of the "Concept of Double Track System".

Double track system is both, the criminal sanctions and the sanctions

11 Sholehuddin, 2004, Double Track System Dan Implementasinya, Rajawali Pers, Jakarta, p. 11 
measures. Double track system does not fully use one of two types of sanctions. This Double track system puts two kinds of sanctions in equally position. Intens to equality criminal sanctions and sanctions within the framework of double-track action system. Exactly linked to the fact that the elements of disapproval/ suffering (through sanctions Criminal) and elements of coaching (through sanctions action) are equally important. Differences Criminal Sanctions and Penalties Measures ${ }^{12}$ :

1. Criminal sanctions stem from the basic idea of "Why is it held convictions" Sanctions Measures departed from the basic idea "For what it's held Punishment"

2. Criminal sanctions actually being reactive to an act. The action is more antipatic sanctions against the perpetrators of such acts.

3. Criminal sanctions more emphasis on the element of vengeance .He is suffering deliberately imposed on the crimes of sanctions measures stressed to the basic idea of community protection and guidance or care to maker.
4. Criminal sanctions focused on criminal who applied for the crimes committed. The sanctions measures have goals that are social.

Double tracks system calls for an element of disapproval / suffering and coaching elements are equally accommodated in law enforcement. This is legal sanctions system on which to base an explanation of why the double track system demanded equality between criminal sanctions and sanctions measures it could applied for drug abusers so that the deterrent effect and the healing process of the drug offenders can run as expected.

\section{CONCLUSION}

The idea of Double Track System demanded equality between Criminal Sanction and sanction the actions it can be applied to the perpetrators of drug abuse so that the deterrent effect and the healing process of the perpetrators of narcotics can run, so that the perpetrators of narcotics and with this process will be able to recover from narcotics user and dependence for their deterrent criminal sanctions. 


\section{BIBLIOGRAPHY}

\section{Books:}

Ali Zaenudin, 2016, Metode Penelitian Hukum, Sinar Grafika, Jakarta.

Badan Narkotika Nasional, 2004, Kampanye Anti Narcotics, Sinar Grafika, Jakarta.

Bambang Waluyo, 2000, Pidana Dan pemidanaan, Sinar Grafika, Jakarta.

Barda Nawawi Arief, 2011, Kebijakan Hukum Pidana Perkembangan Penyusunan Konsep KUHP Baru, Kencana Prenada Group, Jakarta.

Leden Marpaung, 2005, Tindak Pidana Terhadap Nyawa Dan Tubuh, Sinar Grafika Jakarta.

Sholehuddin, 2004, Double Track System Dan Implementasinya, Rajawali Pers, Jakarta.

SR.Sianturi, 2002, Asas-Asas Hukum Pidana Di Indonesia, Rineka Cipta Jakarta.

\section{Regulations:}

Book of Criminal Law

Law No. 22 of 1997 on Narcotics

\section{Others:}

Description Expert Host Winarso the decision of the Constitutional Court of the Republic of Indonesia Number 48 / PUU-IX / 2011.

Expert testimony Asmin Frances the decision of the Constitutional Court of the Republic of Indonesia Number 48 / PUU-IX / 2011. 